\title{
A Method of Product Stock Sharing Within SME's Community Applied in E-Commerce Platform
}

Jumail Wastam (10 ${ }^{1 *}$, Endang Rudiatin (10?

1. Faculty of Engineering, Universitas Muhammadiyah Jakarta, Jakarta 10510, Indonesia

2. Faculty of Social and Politics, Universitas Muhammadiyah Jakarta, Banten 15419, Indonesia

*jumail@umj.ac.id (coresponden author) endang.rudiatin@umj.ac.id

Article history :

Received : 26 Des 2021

Accepted : 28 Des 2021

Available online : 13 Feb 2022

\section{ABSTRACT}

Main problem of community empowerment in Small and Medium Entrepreneurship are the lack of an entrepreneurial ecosystem that helps SME's adopting technology from larger businesses (R\&D transfer). Furthermore, there are various options of platform and opportunity of entrepreneurial available to be utilized, however who concerned on SME's business sustainability are still low. Therefore, an innovation is essential to get SME's more advanced, where the need of customers and their loyalties need to be handled wisely by improving service and business readiness, one of it related to avoiding product stockouts. Forming a SME's community is an alternative that could be explored to maintain business sustainability. Furthermore, e-commerce is a popular business platform that most people access at today shopping trend and SME's may get advantage through it, among other are implementing a method of share product stock. Ensuring that every product you are looking for is still available is essential, because it could increase customer loyalty, with the result that implementation of share product stock method is essential in e-commerce platform within SME's community. An analysis based on the questionnaire are conducted to have public and SME's responds on the experience of using e-commerce, furthermore impact of product stockout to the customer loyalty and important of product stock availability. The result of $98.4 \%$ participant shows positive response that they confidence to have transaction via e-commerce, $85.3 \%$ has shows that product stock availability may maintain customer loyalty, which is it mean that the ecommerce platform and it method of shares product stock have important role to improve SME's business development.

Keywords : Algorithm, business community, e-commerce, sme, share stock method. 


\section{INTRODUCTION}

Small and Medium Enterpreneurships (SME's) taken the largest economic contribution into the national gross domestic income. SME's play an important role in improving national economy with contribution $61,07 \%$ to GDP of Republic of Indonesia at 2020, and targeted increase to $62,36 \%$ at 2021 and will up further to $65 \%$ at 2024 (Linkumkm, 2021). Increasing the number of SME's entrepreneurs is one of the Government's strategies to create new sources of income, create new jobs, and reduce poverty. SME's will play an important role as one of the drivers of economic growth and development. Furthermore, SME's gather many peoples and various businesses. However, as we know that peoples has their dynamic counsumption not only about product but also experiences. Peoples at today trend will not stay at one store to find a product their will take compare and deep much consideration before decide to buy products, so than the store have to prepare for product readiness, includes to make sure product stock availability. However, not all e-commerce platform concern on it, enabling method of product stock sharing within SME's community.

As a note that SME's have to keep inovatif on serving customers to keep trustworthy. Stock availability is one of the important angle that have to be considered by the SME's when their open the store and sell their product throughout online platform. Therefore, SME's Innovation is much encouraged, which is government wish for targeted $65 \%$ contribution of GDP rised from SME's at 2024 (Humas Kementerian Koperasi \& UKM, 2021). Furthermore, SME's have to adapt onto the customer shop characteristic change, especially on their habit on e-commerce transactions which is could be explored by SME's as reference of today shopping trend. Especially in the Covid-19 pandemic as today where the number of unemployed individuals and job losses is increase rapidly where the unemployed reaches 2.67 million or increase of $1.84 \%$ in 2020 compared to the number of unemployed in august at previous year where the total number of unemployed recorded was 9.77 million peoples (Badan Pusat Statistik, 2020; Jayani \& Ridhoi, 2020; Sandi, 2020).

This study is discussed the implementation of product stock sharing method within SME's community development applied in e-commerce to keep product stock availability, which means that the shops could keep ready for the continuous service. User experience in shop and using e-commerce platform will be evaluated. Furthermore, a confirmatory investigation has also conducted to confirm customer thought when they facing product stockout in a destinated shop. Proof on the important of product stock sharing is confirmed also based on feedback on the survey that all gathered via an online questionnaire.

\section{LITERATURE REVIEW}

\subsection{E-Commerce impact to reduce unemployment}

From year to year the number of unemployed in Indonesia has increase contiously, especially since the Covid-19 pandemic in 2019 and peaking in 2020 unemployment increased sharply, contributing to $1.84 \%$ or more than 2.67 million unemployment peoples in August 2020 (Sandi, 2020). Unemployment in 2020 has reached 9.77 million people (Badan Pusat Statistik, 2020; Jayani \& Ridhoi, 2020) and it go higher due to pandemic covide-19 that not yet ended and this is a problem that needs serious attention.

Refer to the finding of the study related to the impact of the e-commerce implementation to employment rate in european union as it has describes by (Gherghina et al., 2021) which from et least $1 \%$ sales will increase 0.2 0.35 percent of employment rate. E-Commerce customers in Indonesia has been increased during the Covid-19 pandemic even for some platform the number of visitor is reaches more than 90 million visitor permonth, and it because the public believe that ecommerce is an online market place that providing more comfortable and flexible to them in doing shopping activities (Dianda \& Pandin, 2021). It shows that ecommerce believed can grow furher and SME's should be involve in taking advantage of today e-commerce development.

\subsection{Potential of SME's and e-commerce in Indonesia}

SME's has their own scope and capacity even though sometimes peoples underestimate to them. Although it looks small in reality, SME's have a very large number of economic potention. As the fact, SME's have potential which is able to make a significant contribution to the national Gross Domestic Product (GDP) as much as IDR 8,400 trillion or around $60 \%$ of GDP in 2018, which national total GDP was IDR 14,000 trillion (Nurdin and T, 2019).

Therefore, refer to the results of Susila's analysis (Susila, 2013), explained that SME's have an important role in national economic development, because of their relatively high in level of labor absorption even with relatively small investment capital requirements SME's are able to answer the problem of unemployability. Futhermore, let be focus on how to maximize potential of existing resources, related to this current study could be mean also to improve the digitial tool that used to 
support business. Related to those analysis point was utilizing e-commerce as a selling media platform is a solution which is the number of user was 158.6 million and even predicted to continue increased to 221 million user in Indonesia at 2025 (Rotar, 2021).

Update with today Covid-19 pandemic that hit globally since 2019 has also attacked the economic in various sectors, including those affected by SME's (Susilawati et al., 2020). Furthemore, disruption of production, transportation, and distribution chains makes it difficult for the economy, operations and management to move in the regulated restriction due to Covid-19 spread prevention (Kumar et al., 2020). Therefore, all issues related to the development SME's business and growth more challenged due to the Covid-19 pandemic, and the innovation in thinking and move to the online or digital solution is offered.

E-Commerce is has been proven survive from the crisis during the Covid-19 pandemic, and a smart way for SME's to transform their selling method from Offline to Online by utilizing e-commerce (Nurlinda \& Sinuraya, 2020). However, what the advantage of e-commerce that SME's should know? Refer of the results research by (Taher, 2021) that e-commerce just as like as a conventional market and transaction which provide enjoyable and benefits to the customers and merchants however it more flexible because the trasaction is not limited to the time and space. Furthermore, e-commerce is one of main criteria of Information technology and communication revolution in the field of economy, which has fundamntally change the current of human life (Nanehkaran, 2013). The experts already expect for the future development of e-commerce since it famously known about 90's, and the features of e-commerce development go advances and continues to facilitates buy and sell transactions, integration with e-payments, building a customer marketplace experience (Zwass, 2015) and now more flexible with multi product selling in a catalogue, easier product management, easier customer management, and as in this research topic concerned on implemenation of SME's community development and product stock sharing method are concerned as such improvement.

\subsection{Product Stock Unavailability and it Consequencies}

Product stock is a collection of products that are available in store and ready to be bought (Law Insider Inc, 2021). In e-commerce product stock availability is important to shows that the store are ready to serve customer in a transaction. Product stock is refer to availability of the product in a store or in a shop that could be formulated with physical stock - reserved stock = available stock (Bruere, 2017). As most definition product stock is refer to availability of the product in a store, so when it finished or stockout so than the transaction couldn't be made.

Furthermore, stockouts may give our costomer in a "Worst Nightmare", and it may lead to lost sales, more after it may resulted to reduced customer satisfaction, disappointment and lowering customers loyalty level (Nicasio, 2021). However, product stockout actually could be acceptable by the customers when the products is categories as high equity product, so than it not effect the customer preferences, other wise customer will see it as a possitive value which product is in high demand because of some reasons (Ding et al., 2015) e.g because of good quality, good prices, and high customer demand. Therefore, SME's or retailer in an e-commerce has always have constraint with some of important features, one of it was the matter of stock, which one of the frequent shared info related to the products and most promotional concern was on stock availability (Shaw, 2000).

\section{RESEARCH METHODOLOGY}

This study are focused in discussing the important of product stock sharing method and SME's community development in an e-commerce platform. The objective of the study was maintain product availability so than the store will stay ready in service. Furthermore, to achieve the objective of the study, a qualitative analysis is conducted based on the questionaire which evaluating the expereince of users in utilizing ecommerce, furthermore confirmatory of their perception when the product is stockout or unavailable in a store they search at.

The target participant of the questionnaire are public in mature age level and SME's community member where expectedly has experience either in buy or sell transaction in e-commerce. Sixty one (61) participants already join the survey and the data has collected as sample.

To shows detail methodology of the study, Fig. 1 is shows the detail phases of the research.

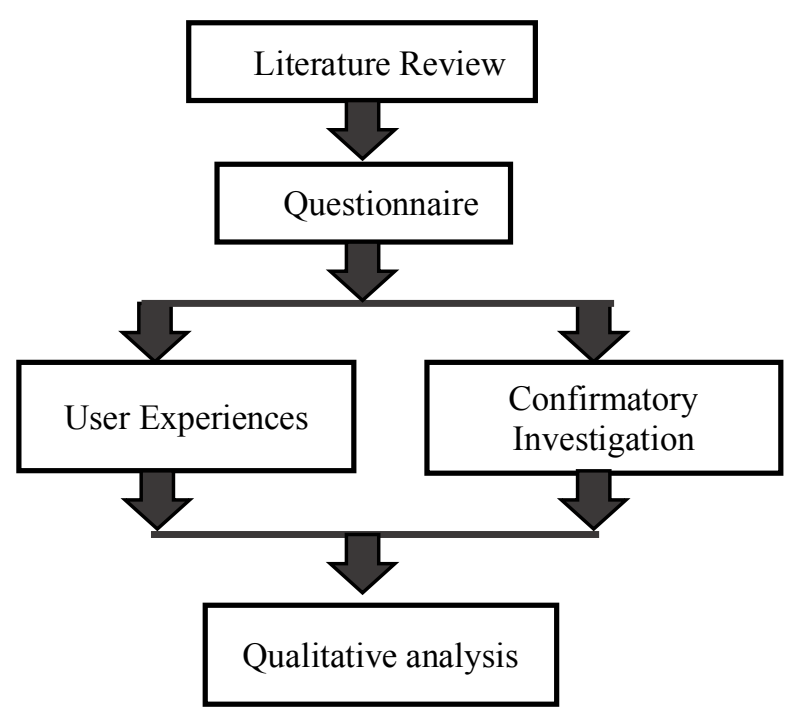

Fig 1. Research methodology.

\section{IMPLEMENTATION}

Product stock sharing method is a proposed model that can be implemented in an e-commerce platform, 
however it should be apply within a SME's community. Therefore, a design of product stock sharing are created to be implemented in E-Commerce to used within a SME's community as a retailer of the shop owners.

A use case diagram in Fig. 2 designed using visual design online free edition (Visual Pradigm Online, 2022) show who may interact with the method in the purpose of utilizing product stock sharing.

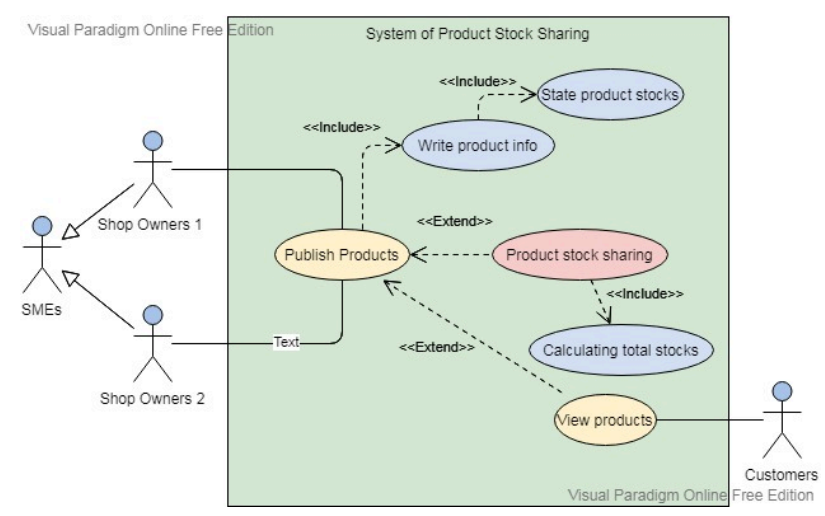

Fig 2. Use case diagram of product stock sharing system.

The implementation procedure of the product stock sharing system in an e-commerce platform may consist of two benefits, first the shop owners will stand as a community member to get more stocks of same products, and second the service will keep ready due to continuous product availability supported by community. The Fig. 3 shows an activity diagram of the system of product stock sharing.

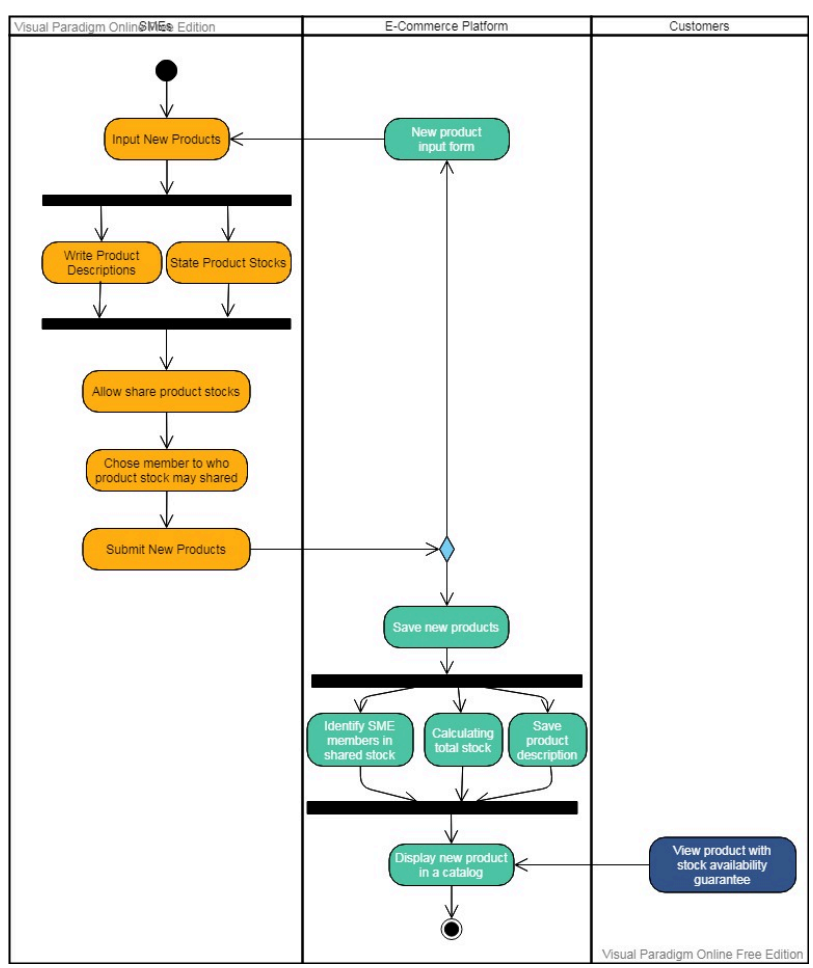

Fig 3. Activity diagram of implementing product stock sharing during input new product into ecommerce product catalog.
Product stock availability is one of the important method that may effect customer satisfaction during their visiting and shopping in an e-commerce platform. Product stockout may degradated the shop readiness and customer loyalty. Therefore, developing SME's community in an e-commerce to allow product stock sharing could alternatively applied as a method to improve stock availability by joining stores in a community with simmilar products.

Within this study a survey has been conducted to evaluate the experience of the public includes the SME's with total 61 respondents has contributes. The survey has completed through an online questionnaire based google form and respondents has completes it online. Furthermore, the survey questions made in Indonesian language, age level of the respondent was in maturity level of age. Goal of the survey was first gathering feedback of public experience in using e-commerce, second is confirmatory of their thought when facing product stockout in a destinated shop.

The Fig. 4 and 5 are shown the ages in detail and the ages in range of the participant who contributes in the survey. Furthermore, Fig. 6 are shows the respondent feedback related to their ecommerce transaction experience and on the important of E-Commerce in today business supports platform.

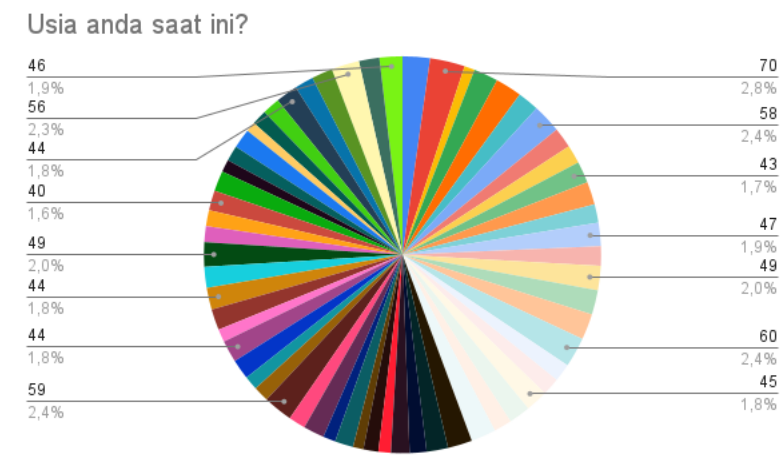

Fig 4. The detail age of the participants.

According to the Fig. 4 and 5, it shows participants who has been contribute in the survey was come from various classification of ages start from 20 years old until 70 years old, classified as mature from the youth age until alderly age classifications which their already have capability to criticize and made personal decision.

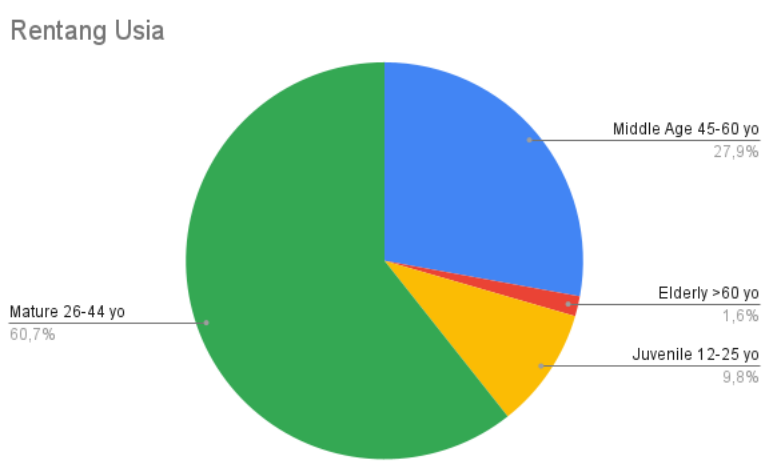

Fig 5. Range age of the participants.

The Fig. 4 shows the range of age that contribute in

\section{DISCUSSIONS}


the survey, and according to (Amin \& Juniati, 2017) at their journal classified the range of age as child (5-11), juvenile (12-25), mature (26-45), elderly (46-65). However in some other study as classified by (Dyussenbayev, 2017) the elderly was classified for the age in average between (60-75) and (44-60) was classified as middle age.

Refer to the Fig. 5 shows that the domination of $60.7 \%$ are in mature ages level and than middle age level at the 2nd with $27.9 \%$ are states that the study have very credible data which collected from very representative age classification and hopefully the people at those classification very much capable to make their own decision properly.

Apakah anda Pernah berbelanja di platform e-commerce? 61 jawaban

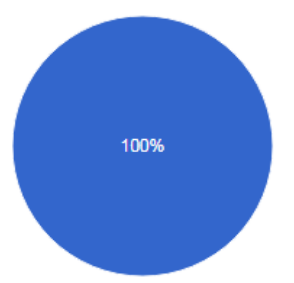

- Ya Tidak

Fig 6. Respondents experience in shopping via ecommerce platform.

The Fig. 6 shows that the respondents involves in the survey entirely $100 \%$ have experience in shopping via ecommerce platform. Furthermore, refer to Fig. 6 and 7 it shows that each respodent have their own preference what they feel and thought when shopping via ecommerce platform. The result shows original respond as in Fig. 7 the result of their shopping experience in ecommerce compared to physical or conventional shopping shows that easier, fun, more save is come as the reason. Specied by the result of the Fig. 8 shows that easier is most reason with 50 of 61 respondents or $83.3 \%$ is thought it. As informations that this question was multiple checkboxes answer, mean each respondent are allowed to select more than one shopping preference accordingly.

How is your experience shopping in e-commerce compared to conventional (physical)?

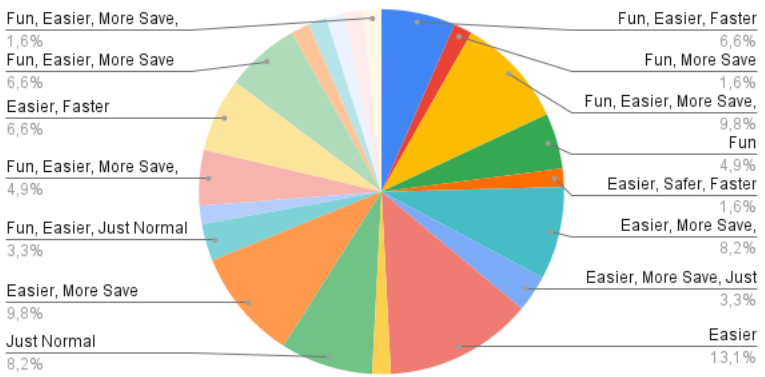

Fig 7. Respondents shopping experience compared to conventional shopping.

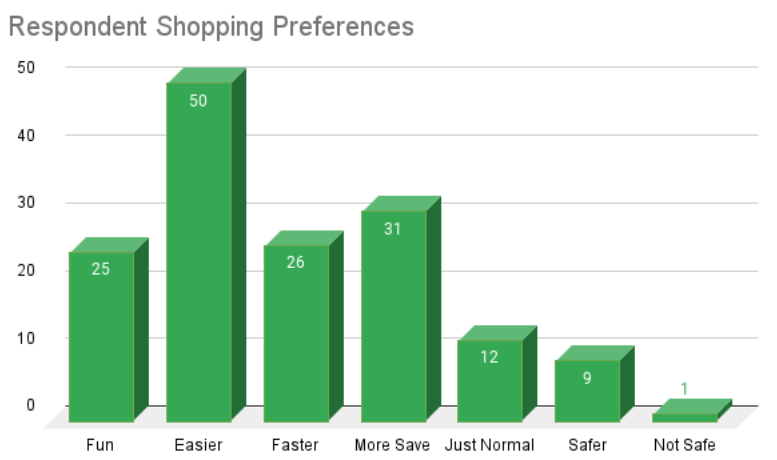

Fig 8. The number of respondent shopping preferences.

As further the confirmatory investigation also conducted to know that the respondents are SME's (business owner) or public, it necessaary to evaluate the preferences of who using e-commerce platform as it is shown in Fig. 9. The 31.1\% respondent was SME's and $68.9 \%$ was public who mostly experienced as the buyer in an e-commerce platform.

Are you SMEs /Business Owner?

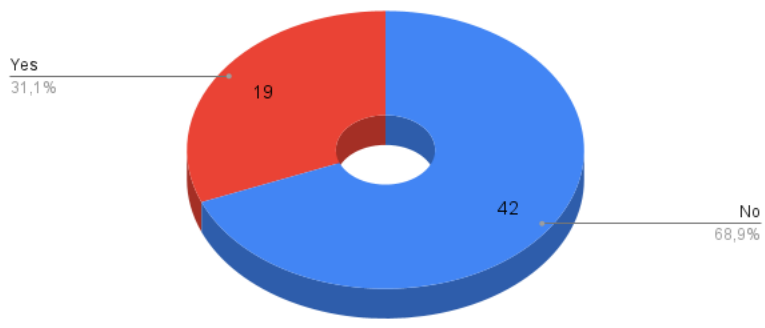

Fig 9. The participation of SME's and Public in the survey.

Refer to Fig. 4 to 9 it confidently shows that ecommerce platform is already fit the target ages level, have expereince in shopping and using e-commerce, and participated by both SME's and public as it has targeted.

Fig. 10 and 11 below shows confirmatory investigation result related to customer experience and thought when facing product unavailability or product stockout in a destinated shop.

\section{Respondent respond on product unavailability}

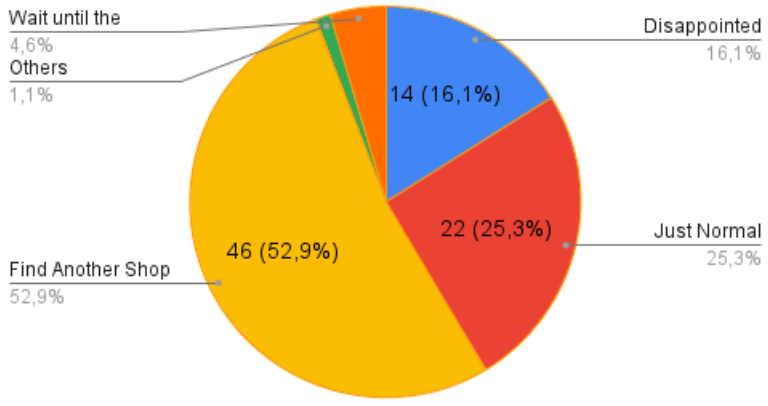


Fig 10. The respondent feedback when facing product unavailability (product stockout).

According to the Fig. 10 it shows that product unavailability or product stockouts may impact to the customer disappoinment (16.1\%) and most customer will alternatively consider to find product from other store $(52.9 \%)$, and only a view will loyaly wait until product available at the same store $(4.6 \%)$, while some respondents still see it as a normal condition (25.3\%). This result confirming that product stockout will reduce customer loyalty as the most and only a view will loyaly wait for the product ready in same store, and a view also see it as a normal condition.

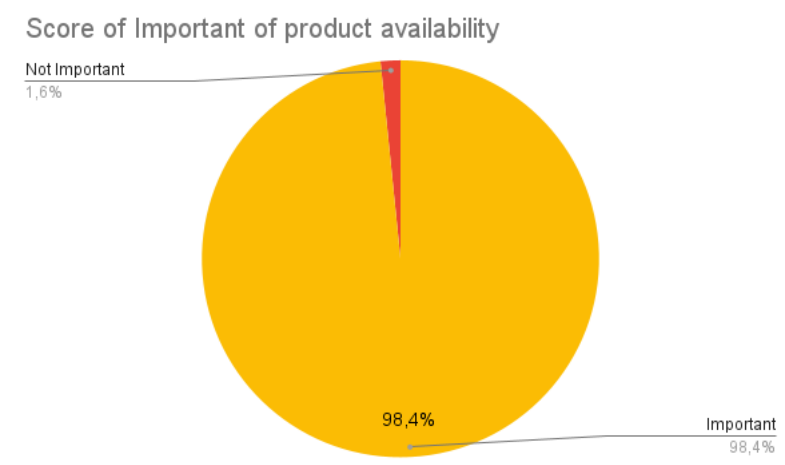

Fig 11. The respondent feedback on the important of stock availability

As shown in Fig. 11 that people was thought that product availability is an important feature that has to be maintain $(98.4 \%)$, it's mean that SME's have to find a way to avoid product stockout. Therefore, a support to the result above, the Fig. 12 shows linierity that product stock availability or readystock will also increase customer confidency to shop in a destinated shop.

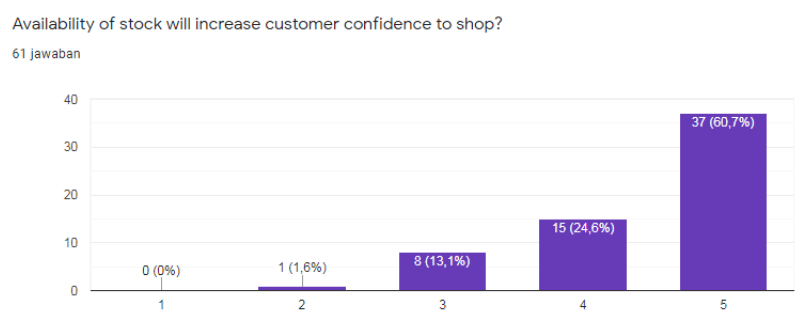

Fig 12. The advantage of product stock availability are increasing customer confidency.

The Fig. 12 is shows that as many as $85.3 \%$ respond in total of Agree (24.6\%) plus Very Agree (60.7\%) that the availability of product stocks will increase customer confidence to keep stay in a destinated shop, while $(13.1 \%)$ respondent considered uncertain and only (1.6\%) shows disagree.

\section{RESULTS AND CONCLUSION}

According to the discussion above it shows that product stock availability is confirmed as one of the important keys that has to be considered to maintain customer confidency and loyalty. SME's should look this as the reference to find the way of product stock maintainability. As in the result shows that (98.4\%) respondent agree that product stock availablity is important, and $(85.3 \%)$ agree to very agree that capability to maintain product stock availability will increase customer confidency to stay loyal to get product from same destinated shop. Furthermore, it was reasonable because the result shows that customer will find another store $(52.9 \%)$ and plus (16.1\%) customer have disappointed in thought when facing product stockout in a destinated shop.

The method of product stock sharing could be an option to keep product availability in a shop. The concept are that each store may share their number of product availability and will joined the product stock with the other store stock within SME's community. The algorithm through a pseudocode writes to show how product stock will stay available and maintain product availability.

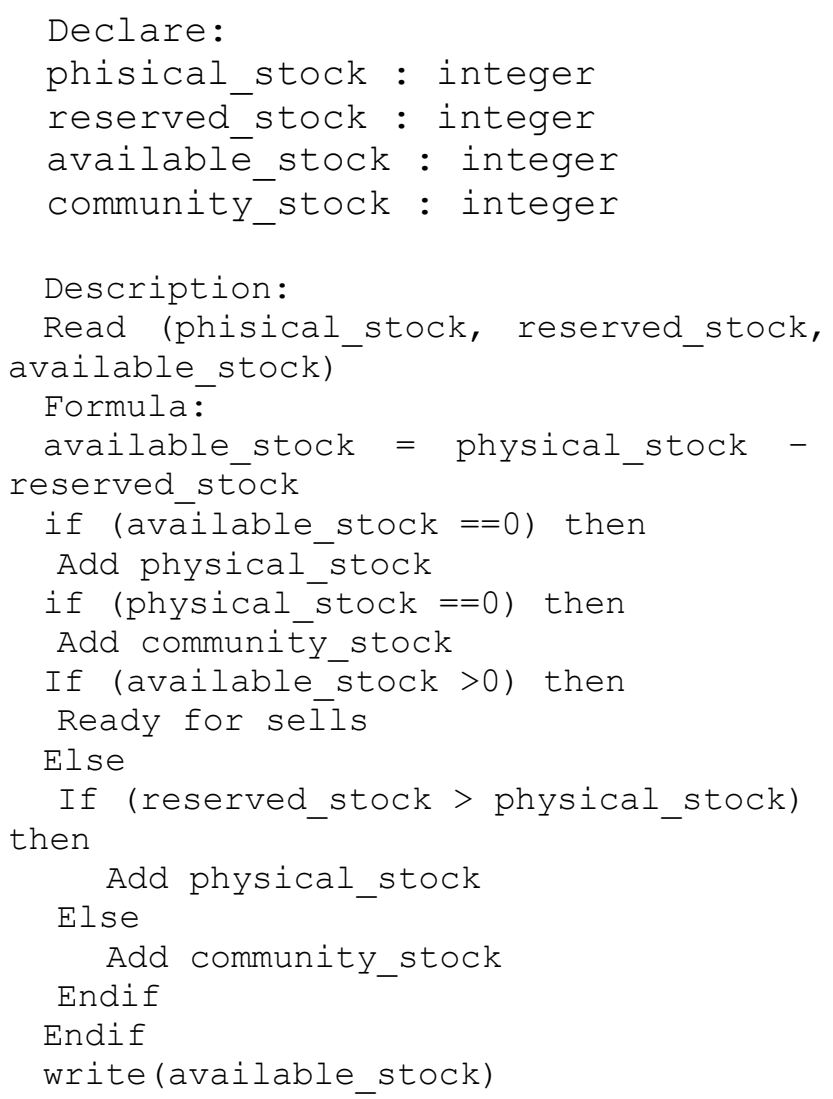

\section{ACKNOWLEDGMENT}

We thanks Riset Muhammadiyah (RisetMu) Majelis Pendidikan Tinggi Penelitian dan Pengembangan, Pimpinan Pusat Muhammadiyah for the fellowship given through Hibah RisetMu Batch V, 2021 so than this study can be published.

\section{REFERENCES}

Amin, M. Al, Juniati, D., 2017. Klasifikasi kelompok umur manusia. MATHunesa 2, 34.

Badan Pusat Statistik, 2020. Pengangguran Terbuka Menurut Pendidikan Tertinggi yang Ditamatkan 1986 - 2020 [WWW Document]. Badan Pus. Stat. URL

https://www.bps.go.id/statictable/2009/04/16/972/pe ngangguran-terbuka-menurut-pendidikan-tertinggi- 
yang-ditamatkan-1986---2020.html 5.25.21).

(accessed

Bruere, G., 2017. Stock Management In PrestaShop 1.7 Part 3 [WWW Document]. prestashop.com. URL https://build.prestashop.com/news/stock-

management-in-prestashop-1-7-part-3/ (accessed 11.15.21).

Shaw M.J. (2000) Electronic Commerce: State of the Art. In: Shaw M., Blanning R., Strader T., Whinston A. (eds) Handbook on Electronic Commerce. International Handbooks on Information Systems. Springer, Berlin, Heidelberg. https://doi.org/10.1007/978-3-642-58327-8_1

Dianda, A., Pandin, M.G.R., 2021. E-Commerce in Strengthening The Economy During The Covid-19 Pandemic: A Historical Review. J. Ekon. Bisnis JAGADITHA 8 , 179-186. https://doi.org/10.22225/jj.8.2.2021.179-186

Ding, J., Lu, Q., Chu, X., 2015. The Effect of Stockout Cause and Brand Equity on Consumer Preference in Online Retailing. Ind. Eng. Manag. Sci. Appl. 2015 349 , 599-608. https://doi.org/https://doi.org/10.1007/978-3-66247200-2 63

Dyussenbayev, A., 2017. Age Periods Of Human Life. Adv. Soc. Sci. Res. J. 4, 258-263. https://doi.org/10.14738/assrj.46.2924

Gherghina, Ștefan C., Botezatu, M.A., Simionescu, L.N., 2021. Exploring the impact of electronic commerce on employment rate: Panel data evidence from european union countries. J. Theor. Appl. Electron. Commer. Res. 16, 3157-3183. https://doi.org/10.3390/jtaer16070172

Humas Kementerian Koperasi dan UKM, 2021. Kemenkopukm Susun 6 Indikator Strategis Adaptasi dan Transformasi KUMKM [WWW Document]. Kemenkop UKM. URL https://kemenkopukm.go.id/read/kemenkopukmsusun-6-indikator-strategis-adaptasi-dantransformasi-kumkm (accessed 11.11.21).

Jayani, D.H., Ridhoi, M.A., 2020. Terdampak Covid-19, Pengangguran Bertambah Jadi 9,77 Juta Orang per Agustus 2020 [WWW Document]. databoks.katadata.co.id. URL https://databoks.katadata.co.id/datapublish/2020/11/ 05/terdampak-covid-19-pengangguran-bertambahjadi-977-juta-orang-per-agustus-2020 (accessed 5.25.21).

Kumar, A., Luthra, S., Mangla, S.K., Kazançoğlu, Y., 2020. COVID-19 impact on sustainable production and operations management. Sustain. Oper. Comput. 1, 1-7. https://doi.org/10.1016/j.susoc.2020.06.001

Law Insider Inc, 2021. Stock Product Definitions [WWW Document]. 2013-2021 Law Insid. Inc. URL https://www.lawinsider.com/dictionary/stockproduct (accessed 11.15.21).

Linkumkm, 2021. Potensi UMKM Mendorong Pembangunan Ekonomi di Indonesia [WWW Document]. LINKUMKM. URL https://linkumkm.id/news/detail/11150/potensiumkm-mendorong-pembangunan-ekonomi-di- indonesia (accessed 11.11.21)

Nanehkaran, Y.A., 2013. An Introduction to Electronic Commerce. Int. J. Sci. Technol. Res. 2, 69-87.

Nicasio, F., 2021. Avoiding Stockouts: 6 Preventable Causes of Out-of-Stocks and What to Do About Them [WWW Document]. vendhq.com. URL https://www.vendhq.com/blog/stockouts/ (accessed 11.17.21).

Nurdin, T, Y., 2019. UMKM Mampu Dorong Pertumbuhan Ekonomi [WWW Document]. pelakubisnis.com. URL http://pelakubisnis.com/2019/09/umkm-mampudorong-pertumbuhan-ekonomi/ (accessed 5.27.21).

Nurlinda, Sinuraya, J., 2020. Potensi UMKM Dalam Menyangga Perekonomian Kerakyatan di Masa Pandemi Covid-19: Sebuah Kajian Literatur. Pros. Semin. Akad. Tah. Ilmu Ekon. dan Stud. Pembang. 2020 160-175.

Visual Paradigm Online, V.D., 2022. Use Case Diagram [WWW Document]. https://online.visualparadigm.com. URL https:/online.visualparadigm.com/ (accessed 1.10.22).

Rotar, A., 2021. Number of e-commerce users in Indonesia from 2017 to 2025.

Sandi, F., 2020. Pengangguran RI "Meledak", Tambah 2,67 Juta Orang Saat Corona [WWW Document]. CNBC Indones. URL https://www.cnbcindonesia.com/news/20201211114 501-4-208391/pengangguran-ri-meledak-tambah267-juta-orang-saat-corona (accessed 5.25.21).

Susila, A.R., 2013. Potensi Ekonomi Daerah Dalam Pengembangan Umkm Unggulan Di Kota Tangerang. Fak. Ekon. Univ. Terbuka.

Susilawati, S., Falefi, R., Purwoko, A., 2020. Impact of COVID-19's Pandemic on the Economy of Indonesia. Budapest Int. Res. Critics Inst. Humanit. Soc. Sci. 3, 1147-1156. https://doi.org/10.33258/birci.v3i2.954

Taher, G., 2021. E-Commerce: Advantages and Limitations. Int. J. Acad. Res. Accounting, Financ. Manag. Sci.

11. https://doi.org/10.6007/ijarafms/v11-i1/8987

Zwass, V., 2015. Electronic commerce: Structures and issues. Int. J. Electron. Commer. 1, 3-23. https://doi.org/10.1080/10864415.1996.11518273

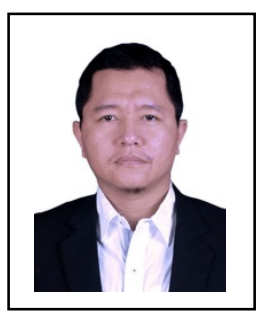

Jumail Wastam received the Master of Science (M.Sc) degree in Information Technology from Universiti Teknologi PETRONAS in 2013. His research interests include web application, multimedia learning, and software engineering.

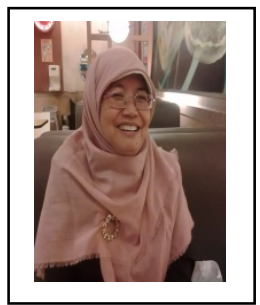

Endang Rudiatin received the Doctorate (Dr) degree in political and social science from Universitas Indonesia in 2012. Her research interests include enterprenership, management, 
business, economic and social politics. 